\title{
PENGARUH PERSEPSI KEMUDAHAN, PERSEPSI KEGUNAAN, PERSEPSI KEUNTUNGAN TERHADAP PENGGUNAAN NYATA DENGAN MINAT PENGGUNAAN SEBAGAI VARIABEL MEDIASI PADA MASYARAKAT GENERASI X DALAM MENGGUNAKAN SISTEM ELECTRONIC MONEY DANA
}

\author{
Robbie \\ Program Studi Magister Manajemen Universitas Tarumanagara \\ robz_chandra@yahoo.co.id \\ Anas Lutfi \\ Program Studi Magister Manajemen Universitas Tarumanagara \\ Masuk : 04-12-2020, revisi : 22-12-2020, diterima untuk diterbitkan : 23-12-2020
}

\begin{abstract}
This research was conducted to know the effect of perceived ease of use, perceived usefulness, and perceived benefit on interest in the use and its impact on real use in $\mathrm{X}$ generation society in using the DANA electronic money system. The research method used is quantitative research methods. The data collection method used was a questionnaire distributed to 100 DANA users who were born in generation X. The data processing method used in this study was Partial Least Square. The results showed that perceived ease of use had no effect on interest in the use and through mediation also did not affect real use decisions. Meanwhile, the perceived usefulness and benefit perception influence the use interest and through mediation also influence the real use decision.
\end{abstract}

Keywords: Perceived Ease of Use, Perceived Usefulness, Perceived Benefit, Interest, Real Use Decision

Abstrak: Penelitian ini dilakukan dengan tujuan untuk mengetahui pengaruh persepsi kemudahan penggunaan, persepsi kegunaan dan manfaat terhadap minat pakai serta pengaruhnya terhadap penggunaan nyata pada masyarakat generasi $\mathrm{X}$ dalam menggunakan sistem uang elektronik DANA. Metode penelitian yang digunakan adalah metode penelitian kuantitatif. Metode pengumpulan data yang digunakan adalah kuesioner yang disebarkan kepada 100 pengguna DANA yang lahir pada angkatan X. Metode pengolahan data yang digunakan dalam penelitian ini adalah Partial Least Square. Hasil penelitian menunjukkan bahwa persepsi kemudahan penggunaan tidak berpengaruh terhadap minat penggunaan dan melalui mediasi juga tidak berpengaruh pada keputusan penggunaan nyata. Sedangkan persepsi kegunaan dan manfaat mempengaruhi kepentingan penggunaan dan melalui mediasi juga mempengaruhi keputusan penggunaan yang sebenarnya.

Kata Kunci: Persepsi Kemudahan, Persepsi Kegunaan, Persepsi Keuntungan, Minat, Penggunaan Nyata

\section{PENDAHULUAN}

Di Indonesia, sistem e-Money atau electronic money sudah diaplikasikan dan terus mengalami pengembangan yang sangat pesat. Hal ini terdukung dengan perkembangan teknologi dan gaya hidup masyarakat. Apalagi dengan adanya fenomena COVID pada tahun 2020, membuat penggunaan sistem e-Money menjadi sistem pembayaran yang paling diutamakan. Hal ini juga terbukti dari jumlah instrumen uang elektronik (e-Money) yang digunakan mengalami lonjakan selama pemberlakuan Pembatasan Sosial Berskala Besar. Pada April 2020, jumlah nya mencapai 412,1 juta, meningkat dari bulan sebelumnya yang sebesar 330,4 juta. Namun pada bulan setelahnya kembali turun menjadi 346,9 juta. 
Namun, walaupun memberikan banyak sekali keuntungan dan keunggulan, masih banyak juga masyarakat yang kurang berminat dalam menggunakan sistem e-Money dalam bertransaksi. Hal ini bisa terjadi dari banyak faktor. Untuk memperkuat pembuktian terhadap penggunaan e-Money, kuesioner awal disebarkan untuk mengetahui minat penggunaan eMoney, terutama pada orang-orang yang lahir pada generasi X. Generasi X adalah orang-orang yang lahir pada periode 1966 - 1976. Orang-orang yang lahir pada periode ini cenderung belum merasakan perkembangan pesat teknologi pada usia muda, sehingga cenderung lebih percaya dengan cara-cara lama.

Dalam penelitian ini, electronic money yang akan diteliti adalah electronic money DANA. Electronic money DANA adalah sebuah electronic money yang sudah bekerja sama dengan banyak brand dan perusahaan keuangan. Bahkan merek dagang sebesar Apple pun dapat melakukan pembayaran menggunakan DANA. Namun, permasalahan yang terjadi adalah hingga saat ini, DANA belum mampu menggeser peringkat OVO dan GOJEK yang terus bertengger di peringkat puncak. Hal ini menjadi permasalahan tersendiri bagi DANA, karena tentunya DANA ingin menjadi pemimpin pasar, dan dengan gap yang masih ada ini, membuat penelitian ini penting untuk dijalankan guna membantu pihak DANA dalam mengembangkan bisnis mereka dan bisa menjadi pemimpin pasar.

\section{Tujuan Penelitian}

Tujuan dari penelitian ini untuk mengetahui pengaruh persepsi kemudahan, persepsi kegunaan, persepsi keuntungan terhadap penggunaan nyata dengan minat penggunaan sebagai variabel mediasi pada masyarakat generasi X dalam menggunakan sistem electronic money DANA.

\section{TINJAUAN PUSTAKA}

\section{Persepsi Kemudahan}

Davis dalam Sugandini et al. (2018) menjelaskan bahwa persepsi kemudahan penggunaan didefinisikan sebagai sejauh mana seseorang percaya bahwa penggunaan teknologi akan bebas dari upaya. Sedangkan menurut Oroh et al. (2015), persepsi kemudahan penggunaan didefinisikan sebagai orang percaya bahwa menggunakan beberapa teknologi tertentuxakan terbebas dari usaha.

Definisi persepsi kemudahan penggunaan (PEU) telah diperdebatkan di antara para peneliti. Menurut Monsuwe, Dellaert, dan Ruyter dalam Yulianita (2018), persepsi kemudahan penggunaan terjadi ketika seseorang percaya bahwa menggunakan teknologi baru akan membebaskannya dari segala upaya selama proses penggunaan teknologi tersebut.

\section{Persepsi Kegunaan}

Kegunaan yang dirasakan didefinisikan sebagai seberapa jauh seseorang percaya bahwa penggunaan teknologi mampu meningkatkan kinerjanya (Davis dalam Sugandini et al., 2018). Orang percaya bahwa menggunakan beberapa teknologi atau sistem tertentu akan dapat meningkatkan keterampilan atau kinerjanya. Seorang individu lebih cenderung berniat untuk melanjutkan penggunaan ketika penggunaan tersebut dianggap bermanfaat.

Persepsi kegunaan dapat dipahami sebagai persepsi individu tentang apakah menggunakan teknologi baru akan meningkatkan atau meningkatkan kinerja mereka dalam melakukan aktivitas tertentu atau tidak (Yulianita, 2018).

\section{Persepsi Keuntungan}

Sebagai definisi umum, manfaat yang dirasakan adalah jumlah keuntungan yang memuaskan kebutuhan dan keinginan konsumen (Wu dalam Sozer \& Civelek, 2018) dan dalam konteks online, itu mencerminkan kepercayaan konsumen tentang sejauh mana ia berada akan menjadi lebih baik dari transaksi online tertentu yang dilakukan di situs web tertentu.

Manfaat yang dirasakan dari belanja online dapat diukur dari tingkat kepuasan atas produk dan manfaat dari belanja online. Menurut Ko et al. dalam Tanadi et al. (2015), manfaat 
yang dirasakan adalah kepercayaan konsumen yang selama ini merasa mereka merasa transaksi online ini jauh lebih baik daripada transaksi online lainnya.

\section{Minat Penggunaan}

Menurut Davis dalam Loanata dan Tileng (2016), minat menggunakan atau intention to use adalah suatu kecenderungan intensi dari pengguna untuk menggunakan teknologi yang diberikan. Tingkat penggunaan sebuah teknologi komputer pada seseorang dapat diprediksi dari sikap perhatiannya terhadap teknologi tersebut, misalnya keinginan menambah peripheral pendukung, motivasi untuk tetap menggunakan, serta keinginan untuk memotivasi pengguna lain.

Niat mewakili instruksi yang diberikan individu untuk berperilaku dengan cara tertentu. Van der Heijdein et al. (2001) mendefinisikan niat pembelian online dengan ambang batas dimana konsumen cenderung membeli produk atau layanan dari situs web tertentu.

\section{Penggunaan Nyata}

Menurut Liao dan Cheung dalam Jahangir dan Begum (2008), Model TAM menunjukkan bahwa perilaku adaptasi pelanggan ditentukan oleh niat untuk menggunakan sistem tertentu, yang pada gilirannya ditentukan oleh persepsi manfaat dan persepsi kemudahan penggunaan sistem. Liao dan Cheung dalam Jahangir dan Begum (2008) menggunakan pendekatan penelitian alternatif yang mengasumsikan bahwa adaptasi pelanggan ditentukan oleh niat untuk melakukan perilaku.

\section{METODOLOGI PENELITIAN}

Penelitian ini menggunakan jenis penelitian kuantitatif dengan pendekatan asosiatif. Jenis penelitian kuantitatif menurut Sugiyono (2017) mendefinisikan sebagai berikut: "Metode penelitian kuantitatif dapat diartikan sebagai metode penelitian yang berlandaskan pada filsafat positivisme, digunakan untuk meneliti pada populasi atau sampel tertentu, pengumpulan data menggunakan instrumen penelitian, analisis data bersifat kuantitatif atau statistik, dengan tujuan untuk menguji hipotesis yang telah ditetapkan.

Teknik pengolahan data yang digunakan dalam penelitian ini adalah regresi partial least square. Regresi Partial Least Square merupakan sebuah metode pengujian dimana pada dasarnya memiliki konsep serupa dengan pengujian regresi parametrik, namun perbedaan antara regresi partial least square dengan regresi sederhana maupun berganda adalah kemampuan dari Partial Least Square dalam mengukur korelasi antara variabel terhadap masing-masing indikator, sehingga regresi dengan Partial Least Square cenderung lebih akurat untuk menunjukkan hasil penelitian. Dalam regresi dengan Partial Least Square, terdapat dua langkah utama yaitu outer model dan inner model.

\section{HASIL DAN KESIMPULAN}

\section{Tabel 1}

Hasil Uji Hipotesis

\begin{tabular}{|c|c|c|c|}
\hline & Original Sample & T Statistics & P Values \\
\hline Minat Penggunaan -> Penggunaan Nyata & 0.665 & 8.406 & 0.000 \\
\hline Persepsi Kegunaan -> Minat Penggunaan & 0.465 & 3.567 & 0.000 \\
\hline Persepsi Kemudahan -> Minat Penggunaan & 0.142 & 1.157 & 0.248 \\
\hline Persepsi Keuntungan -> Minat Penggunaan & 0.296 & 2.383 & 0.018 \\
\hline Persepsi Kegunaan -> Minat Penggunaan -> Penggunaan Nyata & 0.309 & 3.230 & 0.001 \\
\hline Persepsi Kemudahan -> Minat Penggunaan -> Penggunaan Nyata & 0.095 & 1.142 & 0.254 \\
\hline Persepsi Keuntungan-> Minat Penggunaan -> Penggunaan Nyata & 0.197 & 2.221 & 0.027 \\
\hline
\end{tabular}

H1: Persepsi kemudahan berpengaruh signifikan terhadap minat masyarakat generasi $\mathrm{X}$ dalam menggunakan sistem electronic money DANA.

Persepsi kemudahan tidak berpengaruh signifikan terhadap minat masyarakat generasi $\mathrm{X}$ dalam menggunakan sistem electronic money DANA. Dapat disimpulkan bahwa hipotesis yang menyatakan bahwa persepsi kemudahan berpengaruh signifikan terhadap minat masyarakat generasi X dalam menggunakan sistem electronic money DANA ditolak. 
H2: Persepsi kegunaan berpengaruh signifikan terhadap minat masyarakat generasi $\mathrm{X}$ dalam menggunakan sistem electronic money DANA.

Persepsi kegunaan berpengaruh signifikan terhadap minat masyarakat generasi X dalam menggunakan sistem electronic money DANA. Dapat disimpulkan bahwa hipotesis yang menyatakan bahwa persepsi kegunaan berpengaruh signifikan terhadap minat masyarakat generasi $\mathrm{X}$ dalam menggunakan sistem electronic money DANA diterima.

H3: Persepsi keuntungan berpengaruh signifikan terhadap minat masyarakat generasi $\mathrm{X}$ dalam menggunakan sistem electronic money DANA.

Persepsi keuntungan berpengaruh signifikan terhadap minat masyarakat generasi $\mathrm{X}$ dalam menggunakan sistem electronic money DANA. Dapat disimpulkan bahwa hipotesis yang menyatakan bahwa persepsi keuntungan berpengaruh signifikan terhadap minat masyarakat generasi X dalam menggunakan sistem electronic money DANA diterima.

H4: Minat penggunaan berpengaruh signifikan terhadap penggunaan nyata masyarakat generasi $\mathrm{X}$ dalam menggunakan sistem electronic money DANA.

Minat penggunaan berpengaruh signifikan terhadap penggunaan nyata masyarakat generasi X dalam menggunakan sistem electronic money DANA. Dapat disimpulkan bahwa hipotesis yang menyatakan bahwa minat penggunaan berpengaruh signifikan terhadap penggunaan nyata masyarakat generasi $\mathrm{X}$ dalam menggunakan sistem electronic money $\mathrm{DANA}$ diterima.

H5: Minat penggunaan memediasi pengaruh persepsi kemudahan terhadap penggunaan nyata masyarakat generasi $\mathrm{X}$ dalam menggunakan sistem electronic money DANA.

Minat penggunaan tidak memediasi pengaruh persepsi kemudahan terhadap penggunaan nyata masyarakat generasi $\mathrm{X}$ dalam menggunakan sistem electronic money DANA. Dapat disimpulkan bahwa hipotesis yang menyatakan bahwa minat penggunaan memediasi pengaruh persepsi kemudahan terhadap penggunaan nyata masyarakat generasi X dalam menggunakan sistem electronic money DANA ditolak.

H6: Minat penggunaan memediasi pengaruh persepsi kegunaan terhadap penggunaan nyata masyarakat generasi $\mathrm{X}$ dalam menggunakan sistem electronic money DANA.

Minat penggunaan memediasi pengaruh persepsi kegunaan terhadap penggunaan nyata masyarakat generasi $\mathrm{X}$ dalam menggunakan sistem electronic money DANA. Dapat disimpulkan bahwa hipotesis yang menyatakan bahwa Minat penggunaan memediasi pengaruh persepsi kegunaan terhadap penggunaan nyata masyarakat generasi $\mathrm{X}$ dalam menggunakan sistem electronic money DANA diterima.

H7: Minat penggunaan memediasi pengaruh persepsi keuntungan terhadap penggunaan nyata masyarakat generasi $\mathrm{X}$ dalam menggunakan sistem electronic money DANA.

Minat penggunaan memediasi pengaruh persepsi keuntungan terhadap penggunaan nyata masyarakat generasi $\mathrm{X}$ dalam menggunakan sistem electronic money DANA. Dapat disimpulkan bahwa hipotesis yang menyatakan bahwa Minat penggunaan memediasi pengaruh persepsi keuntungan terhadap penggunaan nyata masyarakat generasi $\mathrm{X}$ dalam menggunakan sistem electronic money DANA diterima.

\section{KESIMPULAN}

Persepsi kemudahan tidak berpengaruh signifikan terhadap minat masyarakat generasi $\mathrm{X}$ dalam menggunakan sistem electronic money DANA. Hal ini terjadi karena seseorang yang mengetahui DANA tentunya sudah mengetahui bahwa pembelajaran sistem baru tidak akan mudah dan hal ini dapat membuat seseorang cenderung sulit untuk mengukur kemudahan penggunaan, apalagi untuk generasi $\mathrm{X}$ yang memiliki persepsi kata mudah yang beraneka ragam terhadap sebuah sistem baru sehingga hal ini membuat pengaruh dari persepsi kemudahan tidak signifikan terhadap minat penggunaan.

Persepsi kegunaan berpengaruh signifikan terhadap minat masyarakat generasi $\mathrm{X}$ dalam menggunakan sistem electronic money DANA. Saat seseorang merasakan bahwa penggunaan 
electronic money akan dapat meningkatkan efektifitas dan efisiensi mereka dalam kegiatan bertransaksi sehari-hari, seperti kecepatan membayar, kemudahan membayar dan sebagainya, orang tersebut cenderung akan mencoba untuk mencari tahu lebih dalam mengenai informasi dan akan muncul minat untuk mencoba menggunakan.

Persepsi keuntungan berpengaruh signifikan terhadap minat masyarakat generasi $\mathrm{X}$ dalam menggunakan sistem electronic money DANA. Seseorang yang merasakan bahwa apa yang didapatkan melebihi dari ekspektasi mereka, maka seseorang akan merasakan bahwa electronic money akan menguntungkan mereka, dan di titik inilah seseorang akan berminat menggunakan electronic money.

Minat penggunaan berpengaruh signifikan terhadap penggunaan nyata masyarakat generasi $\mathrm{X}$ dalam menggunakan sistem electronic money DANA. Tingkat penggunaan sebuahxteknologi komputer pada seseorang dapat diprediksixdari sikap perhatiannya terhadap teknologixtersebut, misalnya keinginanan menambahxperipheral pendukung, motivasi untuk tetapxmenggunakan, serta keinginan untuk memotivasixpengguna lain. Saat seseorang sudah termotivasi untuk menggunakan electronic money, dan mendapatkan respon positif dari electronic money tersebut, dan mendapatkan informasi yang lengkap, maka akan memicu respon positif balik dari konsumen, dan salah satunya adalah keputusan konsumen untuk benarbenar menggunakan electronic money tersebut, karena mereka pastinya ingin mendapatkan manfaat lebih dari electronic money tersebut secepat mungkin.

\section{DAFTAR PUSTAKA}

Jahangir, N., \& Begum, N. (2008). The role of perceived usefulness, perceived ease of use, security and privacy, and customer attitude to engender customer adaptation in the context of electronic banking. African Journal of Business Management, 2(1), 32-040. http://www.academicjournals.org/AJBM

Loanata, T., \& Tileng, K. G. (2016). Pengaruh trust dan perceived risk pada intention to use menggunakan Technology Acceptance Model (Studi kasus pada situs E-Commerce Traveloka). JUISI Jurnal Informatika Dan Sistem Informasi, 2(1), 64-73.

Oroh, C. R., Saerang, D. P. E., \& Rumokoy, F. S. (2015). The influence of perceived ease of use, perceived usefulness and trust on repurchase intention of Lion Air e-Ticket. Jurnal Berkala Ilmiah Efisiensi, 15(5), 367-376. https://ejournal.unsrat.ac.id/index.php/jbie/article/view/9844

Sozer, E. G., \& Civelek, M. E. (2018). The effect of perceived benefit on consumer based brand equity in online shopping context. Ege Academic Review, 18(4), 711-725. https://doi.org/10.21121/eab.2018442989

Sugandini, D., Purwoko, Pambudi, A., Resmi, S., Reniati, Muafi, \& Kusumawati, R. A. (2018). The role of uncertainty, perceived ease of use, and perceived usefulness towards the technology adoption. International Journal of Civil Engineering and Technology, 9(4), 660-669.

Sugiyono. (2017). Metode penelitian kuantitatif, kualitatif dan $R \& D$. Alfabeta CV.

Tanadi, T., Samadi, B., \& Gharleghi, B. (2015). The impact of perceived risks and perceived benefits to improve an online intention among generation-Y in Malaysia. Asian Social Science, 11(26), 226-238. https://doi.org/10.5539/ass.v11n26p226

Van der Heijden, H., Verhagen, T., \& Creemers, M. (2001). Predicting online purchase behavior: Replications and test of competing models. Proceedings of the Hawaii International Conference on System Sciences, 196. https://doi.org/10.1109/hicss.2001.927100

Yulianita. (2018). Comparison of generation X and Y: Perceived usefulness, perceived ease of use, and subjective norms on purchase intention in E-Commerce. Jurnal Komunikasi Indonesia, 7(2). https://doi.org/10.7454/jki.v7i2.9677 